\title{
Long-term follow-up of callotasis lengthening of the capitate after resection of the lunate for the treatment of stage III lunate necrosis
}

\author{
Robert Hierner • Klaus Wilhelm
}

Received: 29 March 2009/Accepted: 25 October 2009/Published online: 11 December 2009

(c) Springer-Verlag 2009

\begin{abstract}
The callotasis lengthening technique was used to gradually lengthen the capitate after resection of the lunate in stage IIIa necrosis in 23 patients. Results of ten patients with a follow-up of at least 5 years showed rapid and sufficient callus formation in every patient regardless of age. The callotasis lengthening modification of the Graner II operation provides all advantages and avoids the major inconvenience of the traditional Graner II operation. There was no increased rate of disturbed fracture healing. Results of the DTPA-gadolinium MRI study did not show any significant impairment of vascularization within the region of the capitate bone. With the "intrinsic bone formation," contrary to every other intercarpal arthrodesis at the wrist, there is no need for an additional bone graft.
\end{abstract}

Keywords Hand · Wrist · Lunate · Necrosis · Kienböck · Distraction · Osteogenesis · Partial arthrodesis

R. Hierner dedicates this article to his co-author, Professor Klaus Wilhelm, a great teacher in hand surgery, on the occasion of this 75th birthday.

R. Hierner $(\bowtie)$

Plastic, Reconstructive, Aesthetic and Hand Surgery,

Centre for Interdisciplinary Reconstructive Surgery,

Microsurgery, Replantation, Body Contouring,

Scar Management and Burns, University Hospital Essen,

University Duisburg-Essen, Hufelandstrasse 55,

45147 Essen, Germany

e-mail: robert.hierner@uk-essen.de

K. Wilhelm

Emeritus, Department of Hand Surgery, Ludwig-Maximilians-

University Munich, König Heinrich Strasse 11,

81925 Munich, Germany

\section{Introduction}

Inspite of the patients' excellent subjective judgments of the postoperative results after Graner II operations in case of grade III lunate necrosis, the good functional results and the equal rate of secondary arthritis when compaired to other intercarpal arthrodeses $[1-9,11,14-16,18,21,22$, 24-29, 32-34], this technique nowadays is very rarely used. This is due to its major inconvenience, the risk of disturbed fracture healing leading to pseudarthrosis in about $30 \%$ and/or avascular necrosis of the capitate in 20 $25 \%$ of cases $[11,15,18,24,27]$. Disturbed fracture healing is caused by inadequate capitate osteotomy [14, 15] and/or immediate transfer of the proximal pole with disruption of the nutritient blood vessels [9, 17, 23, 31]. In order to reduce the risk of iatrogenic devascularization of the capitate, the callotasis lengthening techique of Ilizarov [13] has been used after capitate osteotomy between the middle and distal third of the capitate.

\section{Materials and methods}

Twenty-three patients presenting stage IIIa lunate necrosis were operated on using the new technique. The results of ten patients with follow-up of at least 5 years are reported. Preoperative examination included history taking, clinical and radiological examinations (X-ray, DTPA-gadolinium MRI). Intraoperative examination evaluated cartilage and bone quality. Postoperative clinical and radiological examinations (X-ray) were carried out. Active range of motion was measured using the neutral- 0 method. Power and pinch grips were evaluated with the JAMAR ${ }^{\circledR}$ and the Pinch $\operatorname{Meter}_{\circledast}$, respectively. The average of three measurements was noted. The Cooney wrist score was 
Table 1 Therapeutic schedule of callotasis lengthening of the capitate
1. Operative phase
Placing of the distraction device
a. Dorsal skin incision
b. Capsular exposure and partial wrist denervation
c. Capsule incision
d. Scaphoid positioning and temporary K-wire fixation
e. Atraumatic lunate resection
f. Cartilage check (capitate, radius)
g. Determination of osteotomy site
h. Predrilling of pin holes
i. Subperiosteal dissection
j. Transverse capitate osteotomy/corticotomy
k. Pin placement
1. Assembly of distraction device
m. Periosteum/capsule closure
n. Skin closure

2. Predistraction period

7-10 days

Onset of active and passive finger motion

3. Distraction period

Distraction speed $1 \mathrm{~mm} /$ day

4. Consolidation period

Twice as long as distraction period

Replacement of external distraction device by percutaneous K-wires Onset of physical therapy to improove range of motion of the wrist

5. Rehabilitation phase

a. Removal of K-wires

b. Onset of physical therapy to improve grip strength

calculated for functional evaluation. The DASH score was used to evaluate the subjective judgment at the 5-year point. Finally, the functional value of the operation for the patients' professional lives was evaluated according to returning to the previous job, returning to the job after professional retraining or not returning to professional life. Additionally, a postoperative DTPA-gadolinium-enhanced MRJ study was carried out 16 weeks after the operation.

\section{Indication and contraindication}

The callotasis technique for lengthening of the capitate is indicated in cases of stage IIIa lunate necrosis. It is firmly contraindicated in cases were no patient compliance can be expected, like in the case of alcoholics. Because of potential harm to the palmar vessels to the carpal bones, this procedure is containdicated in cases of a previous injury or extensive operation in this region. Severe arthritis at the head of the capitate and the articular surface of the radius are also contraindications for this technique $[2,12$,
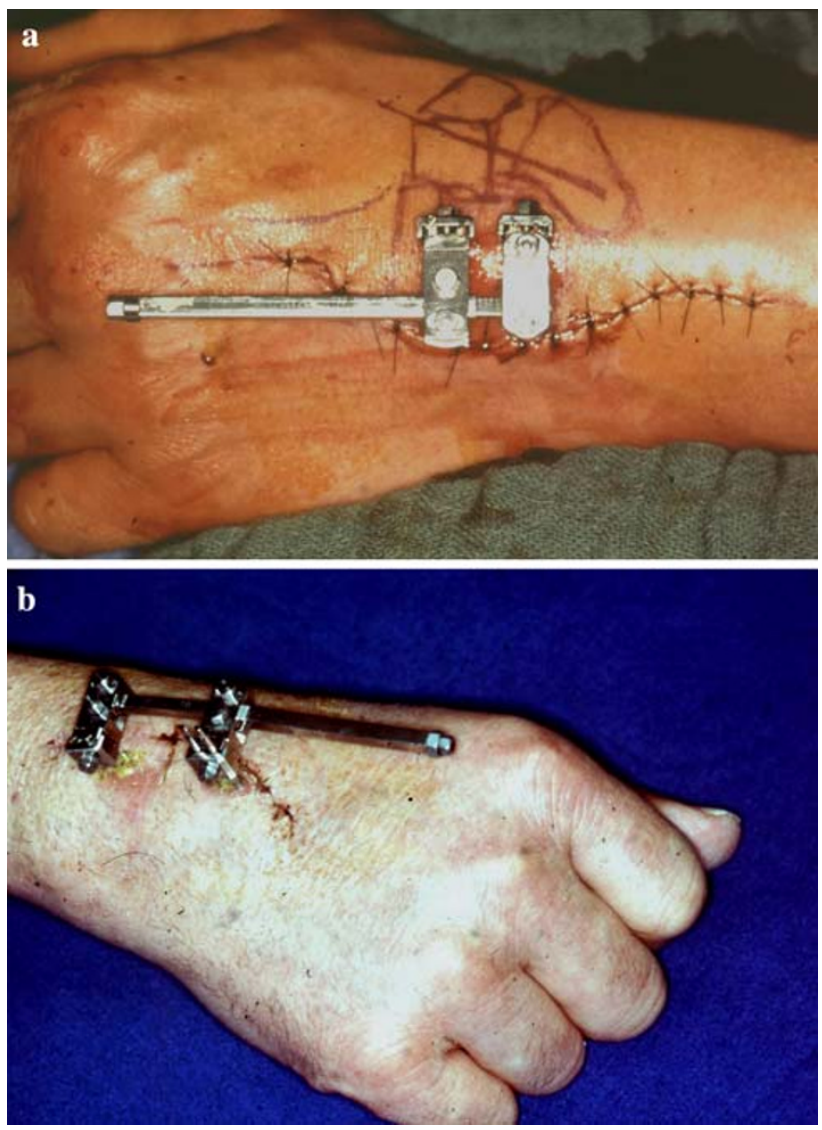

Fig. 1 Clinical aspect during capitate lengthening: a postoperative aspect, b late distraction period (5 weeks)

$21,35]$. In case of a persisting rotatory subluxation of the scaphoid (stage IIIb according to Lichtmann's classification), the new technique is also contraindicated because of lack of definitive fixation of the scaphoid. Impaired soft tissue at the dorsum of the hand is also a contraindication unless reconstructive procedures have preceeded the callotasis lengthening. Because of the reduced potential for bone growth in patients over the age of 25 [13], there might be some impaired bone formation using the callotasis lengthening technique in elderly patients.

Operative technique and postoperative care (Table 1)

The distraction device was developed in cooporation with and supplied by FIXOMED, Munich (Fig. 1).

\section{Results (Table 2, Fig. 2 a-f}

There were eight males and two females. All patients were manual workers. The stage IIIa lunate necrosis was caused by trauma (one case) or by Kienböck's disease (nine cases). The mean age was about 37.9 years (range: $23-55$; Table 2). 


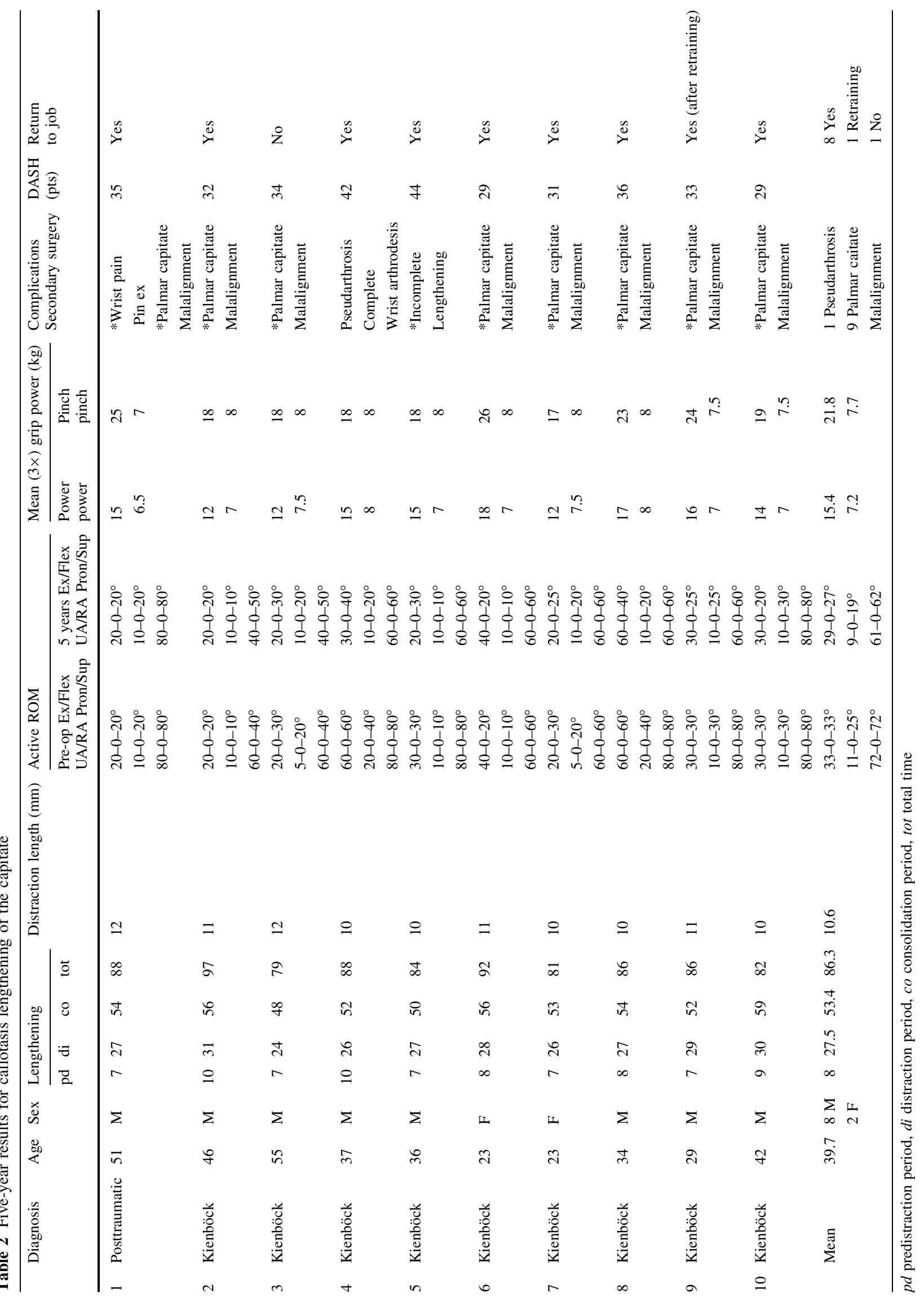



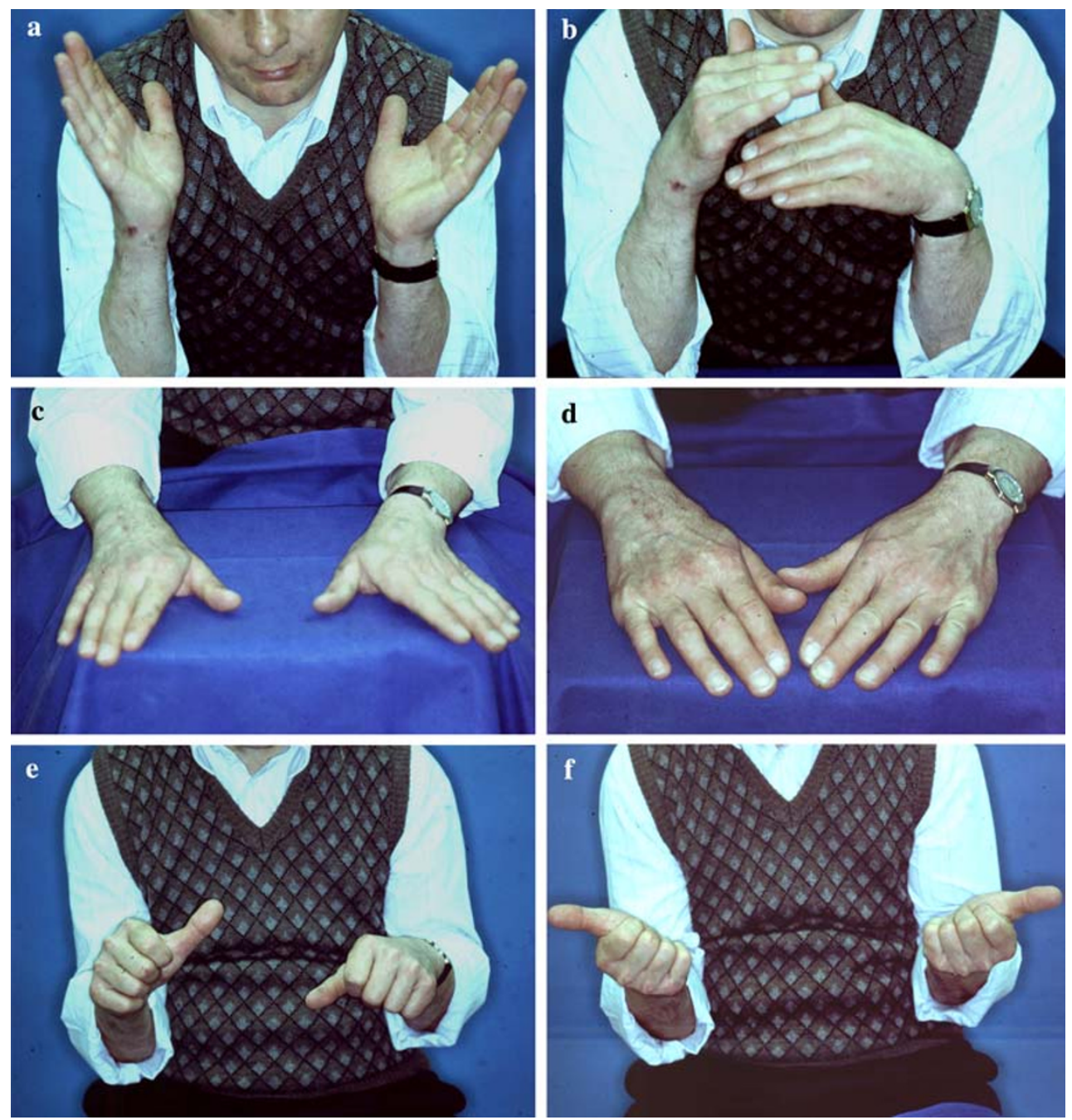

Fig. 2 Active range of motion after 5 years. a Extension, $\mathbf{b}$ flexion, $\mathbf{c}$ ulnar abduction, $\mathbf{d}$ radial abduction, e pronation, $\mathbf{f}$ supination

The mean duration of capitate lengthening (tot) was about 86.3 (range: 79-97) days, with a mean of 8 (range: 7-10) days for the predistraction period (pd), 27.5 (range: 24-31) days for the distraction period (di) and a mean of 53.4 (range: 48-59) days for the consolidation period (co). The mean distraction length was about 10.6 (range: 9-12) $\mathrm{mm}$. The mean range of motion prior to operation was about $33 / 0 / 33^{\circ}$ (range: $20-60 / 0 / 20-60^{\circ}$ ) for extension/flexion, $11 / 0 / 25^{\circ}$ (range: $2-20 / 0 / 10-40^{\circ}$ ) for radial/ulna deviation and $72 / 0 /$ $72^{\circ}$ (range: $60-80 / 0 / 60-80^{\circ}$ ) for prono-supination. The mean range of motion at the 2-year interval was about 29/0/ $27^{\circ}$ (range: $20-30 / 0 / 20-40^{\circ}$ ) for extension/flexion, 9/0/19 (range: $0-10 / 0 / 10-30^{\circ}$ ) for radial/ulnar deviation and 60/0/ $62^{\circ}$ (range: $40-80 / 0 / 50-80^{\circ}$ ) for prono-supination (Fig. 2 af). The mean power grip and pinch grip strength prior to the operation were about 15.4 (range: 12-20) kg and 7.2 (range: $6.5-8) \mathrm{kg}$, respectively. The mean grip and pinch strength at the 5-year interval was about $21.8(17-28) \mathrm{kg}$ and $7.2(6.5-8)$ $\mathrm{kg}$, respectively.
All patients showed good callus formation. In nine cases uneventful bone healing occurred; in one patient a pseudarthrosis within the capitate bone after an attempt to manually correct the sagittal capitate malalignment was seen. In nine patients the MRI study showed complete viability of the proximal and distal part of the capitate (Fig. 3a,b). In one patient (with uneventful bone healing), there was a partial necrosis of the distal capitate segment. Evaluation of the DASH scores showed a mean value of 44.5 points (range, 38-54 points). Eight of ten patients could return to their previous work after a mean of 137 days after the operation. One patient returned to his professional life after retraining. Another patient retired.

\section{Complications}

Mild to moderate pain during the distraction period, especially in the evening, was experienced by all of the 

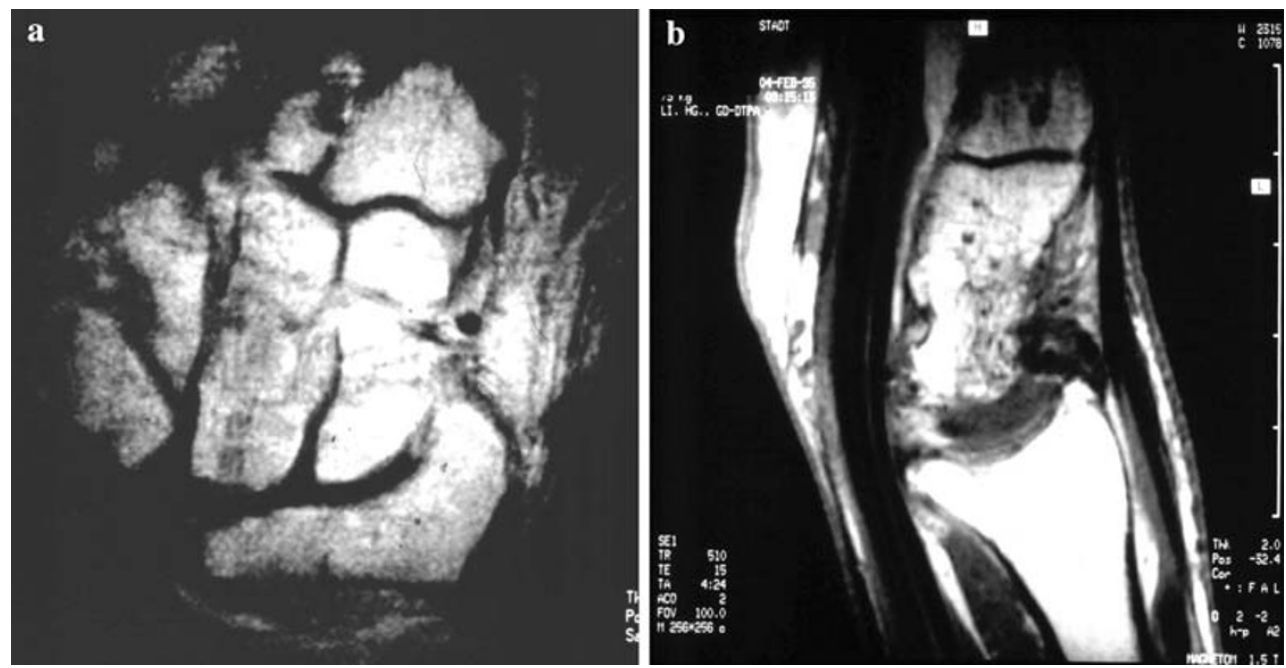

Fig. 3 DTPA- gadolinium-enhanced MRI study of bone viability in the capitate region 16 weeks postoperatively

Fig. 4 Radiological evolution during capitate lengthening (d.p. and lateral view). a Preoperative aspect, $\mathbf{b}$ early distraction period ( 2 weeks), $\mathbf{c}$ late distraction period (4 weeks), d early consolidation period (6 weeks), e late consolidation period (10 weeks), f radiological aspect after 5 years
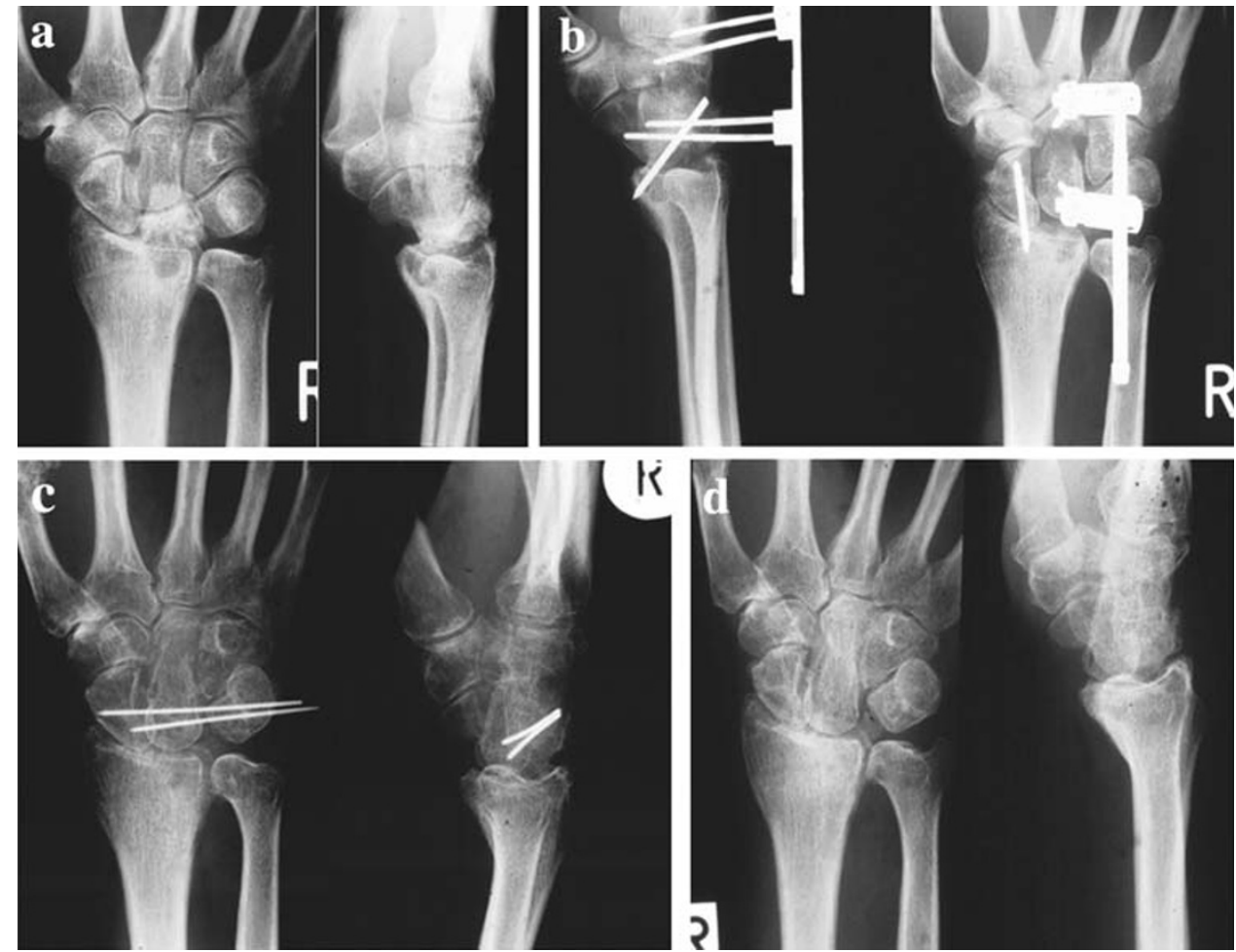

patients; it responded well to the application of NSAR (Diclofenac $50 \mathrm{mg}$ 1-1-1). Severe pain was experienced by one patient, who responded well to paracetamol (500 mg 1-1-1). There were three superficial pin tract infections that could be treated conservatively. Incomplete lengthening of the capitate was seen in one patient who demonstrated limited compliance. In one patient pseudarthrosis occurred after trying to correct the sagittal malalignment deformity of the capitate manually during the distration period. This patient finally required a complete wrist arthrodesis (Table 2). With the ongoing distraction, a sagittal malalignment deformity of the capitate with a mean of $14^{\circ}[10-21]$ occurred in nine of ten patients (Fig. 4b-d).

\section{Discussion}

The aim of the new technique was: (1) to achieve the good functional results of the traditional Graner II technique 
without creating any donor site morbidity for bone graft harvesting and (2) to avoid the risk of avascular necrosis within the capitate bone leading to disturbed fracture healing [35].

Regarding the results of clinical examination, the subjective judgments of our patients were positive due to the excellent pain relief, good preservation of wrist motion and significant increase in grip power. This was also documented by the results of the DASH score. The slight increase in pinch grip power probably should be interpreted more as a result of the physical therapy than the operation itself.

Disturbed fracture healing and avascular necrosis in the capitate region are caused by the osteotomy trauma and more importantly the single-stage capitate lengthening leading to extreme stretching or ultimately rupture of the supplying palmar blood vessels. According to Kerschbauer et al. [15], the appropriate choice of osteotomy site will minimize the osteotomy trauma. Taking into account the extrinsic and intrinsic vascularity of the capitate, the less invasive localization of the ostotomy site is at the junction of the middle to the distal third of the capitate. During progressive capitate lengthening, the proximal fragment, being a capsular pedicled vascularized bone graft, is smoothly shifted towards the radius. There is no excess in stretching the intact palmar blood vessels. Moreover, by progressive distraction, the blood supply will not be disturbed; in contrast, there even will be an increase in vascularity [15]. Thus, the risk of avascular necrosis is diminuished considerably again. Even if the callotaxis lengthening might fail in elderly patients, which never was the case in our series, and therapy must be switched over to the lengthening-interposition technique [12, 19]-the salvage procedure, this advantage will still play a major role.

Regarding the results of the MRI study, there were no significant vascularization defects in the capitate region after callotasis lengthening. Another indirect argument for better vascularization in the callotasis lengthening group is the shorter time of immobilization. Comparing immobilization time after a conventional Graner II operation [21] and our technique, there was a significant reduction from 3 months to 6 weeks.

The first application of the callotasis lengthening technique in the hand was used for posttraumatic cases [19, 20], and these still represent the most common use. Subsequently, the new technique was used to treat congenital hand defomities in children. For treatment of congenital deformities, there are some data in the literature showing that carpal lengthening has been successfully performed $[10,12,30]$. This led to the idea to use this technique in adult patients to lengthen the capitate after lunate resection. Although there are reports in the literature that callus formation might decrease with age, there was sufficient bone formation in all our cases, even in the age group above 30 years. Moreover, no secondary fracture occurred during the consolidation and rehabilitation period. Thus, no bone grafts were needed in any of our patients.

As bone segment shifting and not lengthening is carried out, many soft tissue-related problems such as nerve and vessel stretching, distal joint contractures and fibrosis of the adjacent muscles do not occur. However, there was one specific complication. With the ongoing distraction, a palmar rotation of the proximal shifted capitate segment (Figs. 4b-d, 3b) occurred in nine out of ten patients. This capitate malalignment might be due to the strong palmar ligaments, which could not be sufficiently stretched by the distraction device used. Especially in the late distraction phase, there was some deformation of the distraction device in the sagittal plane. The palmar rotation must be regarded as a "prearthritic defomity" that could lead to accelerated degenerative arthritis at the radiocarpal joint. This complication can only be overcome by using a stronger distraction device. However, up to now no accelerated degenerative changes between the head of the capitate and the radius have been seen.

\section{References}

1. Allieu Y, Chammas M, Lussiez B, Toussiant B, Benichou M, Canovas F (1991) Place del'arthrodèse scapho-rapézo-trapézoidienne dans le traitement de la maladie de Kienböck Ann. Chir Main 10:22-29

2. Braun C, Bühren V (1992) Die Ersatzplastik des Os lunatum durch Interposition des Os capitatum: Operation nach Graner. Oper Orthop Traumatol 4:268-277

3. Buck-Gramcko D (1990) STT-Arthrodese bei karpalen Instabilitäten und Mondbeinnekrose. Operat Orthop Traumatol 2:153159

4. Büchler U (1993) Nécrose avasculaire du semi-lunaire. In: Cahier d'enseignement de la Société Francaise de Chirurgie de la main, Tome 5. Paris: Expansion Scientifique Francaise, pp 1-20

5. Duparc J, Christel P (1978) Traitement chirurgical des nécroses du semilunaire par arthrodèse intercarpienne. Ann Chir 32:565569

6. Feldmeier C, Pöschl M, Seesko H (1987) Aseptische Mondbeinnekrose, Kienböck Erkrankung Hefte zur Unfallheilkunde 184. Springer, Heidelberg

7. Fenollosa JC, Valverde C (1970) Résultats des artrodèses intercarpiennes dans le traitement des nécroses du sémi-lunaire. Rev Chir Orthop 56:745-754

8. Garcia-Elias M, Cooney WP, Linscheid RL, Chao EYS (1989) Wrist kinematics after limited intracarpal arthrodesis. J Hand Surg 14A:791-799

9. Gelberman RH, Panagis JS, Talesnik J, Baumgaertner M (1983) The arterial anatomy of the human carpus. Part I: the extraosseus vascularity. J Hand Surg 8:367-375

10. Golyakhovsky V, Frankel VH (1992) Operative manual of Ilizarov technique. Mosby, St. Louise

11. Graner O, Lopees EI, Carvalho BB, Atlas S (1966) Arthrodesis of the carpal bones in the treatment of Kienböck's disease, painful 
united fractures of the navicular andlunate bones with avascular necrosis and old fracture dislocations of carpal bones. J Bone Jt Surg 48A:764-774

12. Hierner R, Wilhelm K, Kreusser T, Brehl B (1997) Kallusdistraktion zur Verlängerung von Mittelhand und Fingerstümpfen bei angeborenen Fehlbildungen der Hand: Literaturüberblick und eigene Ergebnisse. Handchir Mikrochir Plast Chir 29:1-11

13. Ilizarov GA (1992) Transosseous Osteosynthesis-theoretical and clinical aspects of the regeneration and growth of tissue. Springer, Berlin

14. Kerschbaumer F, Poisel S, Bauer R (1979) Kritische Betrachtung der Capitatumosteotomie zur Behandlung der Lunatummalazie. Handchirurgie 11:105-108

15. Kerschbaumer F, Andree W, Poisel S (1981) Lunatum-Malazie: Vergleich von Kapitatum- Verschiebeplastik und Silastic-Prothese. Orthop 10:52-53

16. Kerschbaumer F, Bauer R (1986) Aseptische Nekrosen im Carpalbereich. Orthop 15:121-130

17. Kuhlmann JN, Guerin-Surville H, Boabighi A (1988) Vascularisation of the carpus, a systematic study. Surg Radiol Anat 10:21-28

18. Leitz G (1982) Ergebnisse einer modifizierten Kapitatumverschiebung bei Lunatummalazie. Handchirurgie 14:106-108

19. Matev IB (1984) Méthode de distraction en chirurgie reconstructive de la main. In: Tubiana R (ed) Traité de chirurgie de la main, Tome II: Techniques chirurgicales, traumatismes de la main. Masson, Paris, pp 429-442

20. Mulliken JB, Curtis RM (1988) Thumb lengthening by metacarpal distraction. J Trauma 20:250-255

21. Naett R, Nonnemacher J, Copin G (1981) Intrakarpale Arthrodese nach Graner. Handchirurgie 13:212-217

22. Partecke BD, Buck-Gramcko D (1985) Technik und Ergebnisse der Sehneninterpositions- Arthroplastik am Mondbein und Kahnbein. Handchirurgie 17:211-218

23. Panagis JS, Gelbermann RH, Talesnik J, Baumgaertner M (1983) The arterial anatomy of the human carpus. Part II: the intraosseous vascularity. J Hand Surg 8:375-382
24. Plaass U (1973) Teilarthrodese des Karpus bei Mondbeinnekrose. Handchirurgie 5:197-200

25. Rogers WD, Watson HK (1989) Radial styloid impingement after triscaphe arthrodesis. J Hand Surg 14A:297-301

26. Saffar P (1982) Remplacement du semilunaire par le pisiforme:description d'une nouvelle technique pour le traitement de la maladie de Kienböck. Ann Chir Main 1:276-279

27. Scharizer E (1988) Interkarpalarthrodesen. In: Bibliotek für Handchirurgie Nigst H (Hrsg) Handgelenksverletzungen. Stuttgart: Hippokrates-Verlag, pp 182-190

28. Steinhäuser J (1981) Langzeiterfahrungen mit der SteinhäuserOperation bei fortgeschrittener Mondbeinnekrose. Orthop 10:5963

29. Swanson A (1973) Flexible implant resection arthroplasty in the hand and extremities. C.V. Mosby Co, St Louise

30. Upton J, Clark H (1991) Allogement progressif des membres. In: Gilbert A, Buck-Gramcko D, Lister G (eds) Les malformation congénitales du membres supérieur. Expansion Scientifique Francaise, Paris, pp 117-129

31. Van der Grand R, Dell PC, Glowczewskie F, Lelie B, Ruby LK (1984) Intraosseus blood supply of the capitate and its correlation with aseptic necrosis. J Hand Surg 9A:677-680

32. Voche P, Bour C, Merle M, Spaite A (1991) L'atrhodèse scaphotrapézo-trapezoidale ou arthrodèse triscaphoide: Etude de 36 cas revus. Rev Chir Orthop 77:103-114

33. Watson HK, Ryu J, Dibella A (1985) An approach to Kienböck's disease: Triscaphe arthrodesis. J Hand Surg 10A:179-187

34. Wilhelm A (1988) Handgelenksdenervation, 194-209. In: Bibliotek für Handchirurgie H. Nigst (Hrsg) Handgelenksverletzungen Hippokrates-Verlag Stuttgart

35. Wilhelm K, Hierner R, Brehl B (1997) Callotaxis lengthening of the capitate after resection of the lunate for the treatment of Kienböck's Disease stage III: operative technique and one-year results. Handchir Mikrochir Plast Chir 29:10-19 